\title{
PENGARUH MODEL PEMBELAJARAN INQUIRY TRAINING TERHADAP KETERAMPILAN PROSES SAINS DAN SIKAP ILMIAH SISWA PADA MATERI POKOK LISTRIK DINAMIS
}

\author{
Yusra Julia Br Maha dan Ida Wahyuni \\ Jurusan Fisika FMIPA Universitas Negeri Medan \\ Jalan Willem Iskandar Pasar V Medan, Sumatera Utara \\ yusrajulia@gmail.com
}

\begin{abstract}
ABSTRAK
Penelitian ini bertujuan untuk mengetahui pengaruh model pembelajaran inquiry training terhadap keterampilan proses sains dan sikap ilmiah siswa pada materi pokok listrik dinamis. Jenis penelitian ini adalah quasi experiment dengan populasi seluruh siswa kelas X MAN Kabanjahe yang terdiri dari 6 kelas. Sampel penelitian diambil 2 kelas dengan teknik cluster random sampling. Instrumen yang digunakan terdiri dari tes keterampilan proses sains berbentuk uraian, lembar observasi keterampilan proses sains, dan tes sikap ilmiah menggunakan angket. Pengujian hipotesis dilakukan pada data yang berdistribusi normal dan homogen. Hasil penelitian menunjukkan bahwa terdapat pengaruh model pembelajaran inquiry training terhadap keterampilan proses sains dan sikap ilmiah siswa pada materi pokok listrik dinamis.
\end{abstract}

Kata kunci : inquiry training, keterampilan proses sains, sikap ilmiah

\begin{abstract}
The research was aimed to determine the effect of inquiry training learning model of science process skill and scientific attitude of students in the subject of dynamic electricity. Type of this research was quasi experiment with the entire student population of class X MAN Kabanjahe that consisted 6 classes. Samples were taken 2 classes with cluster random sampling technique. The instrument used consisted of test of science process skill in the form of essay, observation of science process skill, and test the scientific attitude used questionnaire. The testing of hypotheses done on the normal distribution data and homogeneous. The result showed that there was effect of inquiry training learning model of science process skill and scientific attitude of students in the subject of dynamic electricity.
\end{abstract}

Keywords : inquiry training, science process skill, scientific attitude 
PENDAHULUAN

Berkembangnya

pendidikan sudah

berpengaruh

pasti

terhadap

perkembangan ilmu pengetahuan

dan teknologi. Pesatnya

perkembangan ilmu pengetahuan

dan teknologi sekarang ini tidak

dapat terlepas dari kemajuan

sains. Sains didefinisikan

sebagai sekumpulan teori yang

sistematis, penerapannya secara

umum terbatas pada gejala-gejala

alam, lahir dan berkembang

melalui metode ilmiah dan

eksperimen serta menuntut sikap ilmiah.

Menurut Puskur (Trianto, 2013), sains pada hakikatnya meliputi empat unsur utama yaitu: (1) sikap: rasa ingin tahu tentang benda, fenomena alam, makhluk hidup, serta hubungan sebab akibat yang menimbulkan masalah baru yang dapat dipecahkan melalui prosedur yang benar; (2) proses: prosedur pemecahan masalah melalui metode ilmiah; (3) produk: berupa fakta, konsep, prinsip, teori, dan hukum; dan (4) aplikasi: penerapan metode ilmiah dan konsep sains dalam kehidupan sehari-hari.

Fisika sebagai bagian dari sains merupakan ilmu pengetahuan yang mempelajari gejala-gejala alam melalui serangkaian proses ilmiah yang dibangun atas dasar sikap ilmiah dan hasilnya terwujud sebagai produk ilmiah yang tersusun atas tiga komponen terpenting berupa konsep, prinsip, dan teori yang berlaku secara universal.
Kenyataannya siswa jarang dibawa ke dalam proses ilmiah melalui praktikum. Hal ini terbukti dari hasil studi pendahuluan yang dilakukan peneliti pada tanggal 21 Januari 2015 dengan menggunakan angket. Dari hasil studi pendahuluan disimpulkan bahwa proses pembelajaran berlangsung dengan mencatat dan mengerjakan soal-soal. Hasil wawancara dengan guru fisika di sekolah tersebut juga mengatakan bahwa beliau jarang membawa siswa ke laboratorium. Hal ini terjadi karena adanya kendala yang dihadapi dalam penerapannya, yaitu waktu yang terbatas, alat dan bahan praktikum yang belum memadai, dan banyaknya materi yang harus dipelajari.

Keterampilan proses sains di sekolah kebanyakan digunakan untuk menguji konsep yang telah ada. Dengan adanya keterampilan proses sains, akan timbul sikap ilmiah yang diperlukan dalam penemuan ilmu pengetahuan.

Dengan mengembangkan keterampilan proses sains, siswa akan mampu menemukan dan mengembangkan sendiri fakta dan konsep serta menumbuhkan dan mengembangkan sikap ilmiah siswa. Namun, kegiatan praktikum yang jarang dilakukan akan mengakibatkan keterampilan proses sains siswa tidak berkembang dan berdampak juga kepada sikap ilmiah siswa. Sehingga siswa tidak dapat menumbuhkan dan 
mengembangkan sikap ilmiah mereka.

Menurut Indrawati (Trianto, 2013), keterampilan proses sains merupakan keseluruhan keterampilan ilmiah yang terarah (baik kognitif maupun psikomotor) yang dapat digunakan untuk menemukan suatu konsep, prinsip atau teori untuk mengembangkan konsep yang telah ada sebelumnya, ataupun untuk melakukan penyangkalan terhadap suatu penemuan.

Menurut National Society of Study Education (NSSE) (Rao, 2007), sikap ilmiah dapat didefinisikan sebagai keterbukaan pikiran, keinginan terhadap pengetahuan yang akurat, percaya pada prosedur dalam mencari pengetahuan dan harapan bahwa solusi dari masalah akan datang melalui pengujian pengetahuan.

Berdasarkan masalah yang telah dikemukakan dapat diupayakan pemecahannya yaitu dengan mencoba tindakan tindakan yang dapat mengembangkan keterampilan proses sains dan sikap ilmiah siswa. Salah satu model pembelajaran yang dapat digunakan adalah model pembelajaran inquiry training. Menurut Joyce, dkk., (2011), model pembelajaran inquiry training dirancang untuk membawa siswa secara langsung ke dalam proses ilmiah melalui latihan-latihan yang dapat memadatkan proses ilmiah tersebut ke dalam waktu yang singkat.
Hasil pembelajaran utama dari model inquiry training adalah keterampilan proses sains yang melibatkan aktivitas observasi, mengumpulkan dan mengolah data, mengidentifikasi dan mengontrol variabel, membuat dan menguji hipotesis, merumuskan penjelasan, dan menggambarkan kesimpulan. Sintaks model pembelajaran inquiry training yaitu: menghadapkan pada masalah, pengumpulan data-verifikasi, pengumpulan dataeksperimentasi, mengolah, memformulasikan suatu penjelasan, analisis proses peneletian.

Keterampilan proses sains akan menimbulkan sikap ilmiah yang diperlukan dalam penemuan ilmu pengetahuan. Penerapan keterampilan proses sains akan membantu siswa menemukan dan mengembangkan sendiri fakta dan konsep serta menumbuhkan sikap ilmiah siswa.

Penelitian mengenai model pembelajaran inquiry training sudah pernah diteliti oleh peneliti sebelumnya yaitu Sakdiah dan Sahyar (2014) menyimpulkan bahwa terdapat interaksi antara model pembelajaran inquiry training berbantukan media handout dan direct instruction dengan sikap ilmiah siswa dalam meningkatkan pengetahuan siswa berbasis KPS dan interaksi pada kelas direct instructional lebih baik.

Damanik dan Bukit (2012) menyimpulkan bahwa kemampuan berpikir kritis fisika siswa yang menggunakan model 
pembelajaran inquiry training lebih baik dibandingkan dengan kemampuan berpikir kritis siswa yang menggunakan model pembelajaran direct instruction, namun tidak terdapat interaksi antara model pembelajaran inquiry training dan direct instruction pada kemampuan berpikir kritis untuk meningkatkan sikap ilmiah siswa.

Penelitian ini bertujuan untuk mengetahui pengaruh model pembelajaran inquiry training terhadap keterampilan proses sains dan sikap ilmiah siswa pada materi pokok listrik dinamis.

\section{METODE PENELITIAN}

Penelitian ini dilaksanakan di MAN Kabanjahe yang beralamat di jalan Samura, gang Madrasah no.6 Kabanjahe pada bulan Mei semester II T.P. 2014/2015. Pengambilan sampel menggunakan teknik cluster random sampling sebanyak dua kelas yaitu kelas X-1 sebanyak 34 siswa sebagai kelas eksperimen diterapkan model pembelajaran inquiry training dan kelas X-2 sebanyak 35 siswa sebagai kelas kontrol diterapkan pembelajaran konvensional.

Penelitian ini menggunakan dua variabel yaitu variabel bebas berupa model pembelajaran inquiry training dan pembelajaran konvensional, dan variabel terikat berupa keterampilan proses sains dan sikap ilmiah siswa.

Jenis penelitian ini adalah quasi experiment dengan desain the pre-test-post-test control group. Instrumen yang digunakan terdiri dari tes keterampilan proses sains berbentuk uraian sebanyak 10 soal, lembar observasi keterampilan proses sains, dan tes sikap ilmiah menggunakan angket berjumlah 25 pernyataan.

Pengujian hipotesis menggunakan uji $t$ pada taraf signifikan $5 \%$ dengan uji prasyarat normalitas dan homogenitas. Uji normalitas bertujuan untuk memeriksa apakah data berdistribusi normal atau tidak, uji yang digunakan adalah uji Lilliefors. Uji Homogenitas dilakukan untuk mengetahui apakah data sampel yang diambil memiliki varians yang homogen atau tidak (Sudjana, 2005). Data lembar observasi keterampilan proses sains dianalisis menggunakan statistik deskriptif.

\section{HASIL DAN PEMBAHASAN}

Data pre-test dan post-test keterampilan proses sains kelas eksperimen ditunjukkan pada Tabel 1.

Tabel 1. Persentase

Keterampilan

Proses Sains Kelas Eksperimen

\begin{tabular}{|c|c|c|c|c|}
\hline \multirow{2}{*}{$\begin{array}{c}\text { Keterampil } \\
\text { an Proses } \\
\text { Sains }\end{array}$} & \multicolumn{2}{|c|}{ Pre-test } & \multicolumn{2}{|c|}{ Post-Test } \\
\hline & $\begin{array}{c}\text { Nil } \\
\text { ai } \\
(\%)\end{array}$ & $\begin{array}{l}\text { Kate } \\
\text { gori }\end{array}$ & $\begin{array}{c}\text { Nilai } \\
(\%)\end{array}$ & $\begin{array}{c}\text { Kat } \\
\text { egor } \\
\text { i }\end{array}$ \\
\hline Mengamati & $\begin{array}{c}41 . \\
9\end{array}$ & $\begin{array}{c}\text { Gaga } \\
1\end{array}$ & 79.4 & $\begin{array}{c}\text { Bai } \\
\mathrm{k}\end{array}$ \\
\hline $\begin{array}{l}\text { Mengumpu } \\
\text { lkan dan }\end{array}$ & $\begin{array}{c}33 . \\
5\end{array}$ & $\begin{array}{c}\text { Gaga } \\
1\end{array}$ & 71.7 & $\begin{array}{c}\text { Bai } \\
\mathrm{k}\end{array}$ \\
\hline
\end{tabular}


Mengolah

Data

\begin{tabular}{|c|c|c|c|c|}
\hline $\begin{array}{l}\text { Mengidenti } \\
\text { fikasi dan } \\
\text { Mengontro } \\
1 \text { Variabel }\end{array}$ & $\begin{array}{c}38 . \\
2\end{array}$ & $\begin{array}{c}\text { Gaga } \\
1\end{array}$ & 64.7 & $\begin{array}{c}\text { Cuk } \\
\text { up }\end{array}$ \\
\hline $\begin{array}{l}\text { Membuat } \\
\text { dan } \\
\text { Menguji } \\
\text { Hipotesis }\end{array}$ & $\begin{array}{c}23 . \\
5\end{array}$ & $\begin{array}{c}\text { Gaga } \\
1\end{array}$ & 53.7 & $\begin{array}{c}\text { Gag } \\
\text { al }\end{array}$ \\
\hline $\begin{array}{l}\text { Merumusk } \\
\text { an } \\
\text { Penjelasan }\end{array}$ & $\begin{array}{c}58 . \\
5\end{array}$ & $\begin{array}{c}\text { Kura } \\
\text { ng }\end{array}$ & 69.5 & $\begin{array}{c}\text { Cuk } \\
\text { up }\end{array}$ \\
\hline $\begin{array}{l}\text { Menggamb } \\
\text { arkan } \\
\text { Kesimpula } \\
\text { n }\end{array}$ & $\begin{array}{c}50 . \\
4\end{array}$ & $\begin{array}{c}\text { Kura } \\
\text { ng }\end{array}$ & 76.8 & $\begin{array}{c}\text { Bai } \\
\mathrm{k}\end{array}$ \\
\hline
\end{tabular}

Tabel 1 menunjukkan bahwa aspek setiap keterampilan proses sains kelas eksperimen setelah menggunakan model pembelajaran inquiry training mengalami peningkatan. Keterampilan proses sains pada kategori baik terjadi pada aspek mengamati, mengumpulkan dan mengolah data, dan menggambarkan kesimpulan. Hal ini terjadi karena siswa sudah terampil saat melakukan eksperimen.

Keterampilan proses sains pada kategori cukup terjadi pada aspek mengidentifiksi dan mengontrol variabel, dan merumuskan penjelasan. Hal ini terjadi karena siswa sudah cukup terampil saat eksperimen.

Keterampilan proses sains pada kategori gagal terjadi pada aspek membuat dan menguji hipotesis. Walaupun aspek membuat dan menguji hipotesis mengalami peningkatan, namun siswa masih banyak yang gagal pada aspek ini. Hal ini terjadi karena hipotesis siswa masih banyak yang tidak sesuai dengan konsep dan mengalami kesulitan untuk menguji hipotesis sehingga menyebabkan hipotesis siswa sangat rendah.

Data pre-test dan post-test keterampilan proses sains kelas kontrol ditunjukkan pada Tabel 2 .

Tabel 2. Persentase

Keterampilan Proses Sains Kelas

\begin{tabular}{|c|c|c|c|c|}
\hline \multicolumn{5}{|c|}{ Kontrol } \\
\hline \multirow{2}{*}{$\begin{array}{c}\text { Keterampila } \\
\text { n Proses } \\
\text { Sains }\end{array}$} & \multicolumn{2}{|c|}{ Pre-test } & \multicolumn{2}{|c|}{ Post-Test } \\
\hline & $\begin{array}{l}\mathrm{Nil} \\
\text { ai } \\
(\%)\end{array}$ & $\begin{array}{l}\text { Kate } \\
\text { gori }\end{array}$ & $\begin{array}{l}\text { Nil } \\
\text { ai } \\
(\%)\end{array}$ & $\begin{array}{l}\text { Kate } \\
\text { gori }\end{array}$ \\
\hline Mengamati & $\begin{array}{c}53 . \\
7\end{array}$ & $\begin{array}{c}\text { Kura } \\
\text { ng }\end{array}$ & $\begin{array}{c}73 . \\
2\end{array}$ & Baik \\
\hline $\begin{array}{l}\text { Mengumpulk } \\
\text { an dan } \\
\text { Mengolah } \\
\text { Data }\end{array}$ & $\begin{array}{c}35 . \\
7\end{array}$ & Gagal & $\begin{array}{c}69 . \\
9\end{array}$ & $\begin{array}{l}\text { Cuk } \\
\text { up }\end{array}$ \\
\hline $\begin{array}{l}\text { Mengidentifi } \\
\text { kasi dan } \\
\text { Mengontrol } \\
\text { Variabel }\end{array}$ & $\begin{array}{c}33 . \\
1\end{array}$ & Gagal & $\begin{array}{c}72 . \\
1\end{array}$ & Baik \\
\hline $\begin{array}{l}\text { Membuat } \\
\text { dan Menguji } \\
\text { Hipotesis }\end{array}$ & $\begin{array}{c}11 . \\
0\end{array}$ & Gagal & $\begin{array}{c}22 . \\
8\end{array}$ & $\begin{array}{c}\text { Gaga } \\
1\end{array}$ \\
\hline $\begin{array}{l}\text { Merumuskan } \\
\text { Penjelasan }\end{array}$ & $\begin{array}{c}40 . \\
8\end{array}$ & Gagal & $\begin{array}{c}62 . \\
1\end{array}$ & $\begin{array}{l}\text { Cuk } \\
\text { up }\end{array}$ \\
\hline $\begin{array}{l}\text { Menggambar } \\
\text { kan } \\
\text { Kesimpulan }\end{array}$ & $\begin{array}{c}52 . \\
6\end{array}$ & $\begin{array}{l}\text { Kura } \\
\text { ng }\end{array}$ & $\begin{array}{c}72 . \\
8\end{array}$ & Baik \\
\hline
\end{tabular}


Tabel 2 menunjukkan bahwa aspek setiap keterampilan proses sains kelas kontrol mengalami peningkatan. Keterampilan proses sains pada kategori baik terjadi pada aspek mengamati, mengidentifikasi dan mengontrol variabel, dan menggambarkan kesimpulan. Hal ini terjadi karena siswa sudah terampil saat melakukan eksperimen. Keterampilan proses sains pada kategori cukup terjadi pada aspek mengumpulkan dan mengolah data, dan merumuskan penjelasan. Hal ini terjadi karena siswa sudah cukup terampil saat eksperimen.

Keterampilan proses sains pada kategori gagal terjadi pada aspek membuat dan menguji hipotesis. Walaupun aspek membuat dan menguji hipotesis mengalami peningkatan, namun siswa masih banyak yang gagal pada aspek ini. Hal ini terjadi karena hipotesis siswa masih banyak yang tidak sesuai dengan konsep dan mengalami kesulitan untuk menguji hipotesis sehingga menyebabkan hipotesis siswa sangat rendah.

Keterampilan proses sains kedua kelas setelah diberi perlakuan mengalami peningkatan. Namun, keterampilan proses sains pada kelas eksperimen lebih tinggi dibandingkan dengan kelas kontrol. Hal ini terjadi karena model pembelajaran inquiry training memiliki kelebihan yaitu dapat membantu siswa untuk mengkonstruksi langsung pengetahuan melalui setiap kegiatan yang telah dirancang pada fase inquiry training. Pengaruhnya adalah model pembelajaran inquiry training akan meningkatkan pemahaman ilmu pengetahuan, produktivitas dalam berpikir kreatif, dan keterampilan-keterampilan dalam memperoleh dan menganalisis informasi.

Data pre-test dan post-test sikap ilmiah kelas eksperimen ditunjukkan pada Tabel 3 .

Tabel. 3 Persentase Sikap Ilmiah Kelas Eksperimen

\begin{tabular}{|c|c|c|c|c|}
\hline \multirow[b]{2}{*}{ Sikap Ilmiah } & \multicolumn{2}{|c|}{ Pre-test } & \multicolumn{2}{|c|}{ Post-Test } \\
\hline & $\begin{array}{l}\text { Nil } \\
\text { ai } \\
(\%)\end{array}$ & $\begin{array}{l}\text { Kate } \\
\text { gori }\end{array}$ & $\begin{array}{l}\mathrm{Nil} \\
\text { ai } \\
(\%)\end{array}$ & $\begin{array}{r}\text { Kate } \\
\text { gori }\end{array}$ \\
\hline Rasional & $\begin{array}{c}71 . \\
9\end{array}$ & Baik & $\begin{array}{c}77 . \\
8\end{array}$ & Baik \\
\hline Ingin Tahu & $\begin{array}{c}78 . \\
8\end{array}$ & Baik & $\begin{array}{c}85 . \\
6\end{array}$ & $\begin{array}{c}\text { San } \\
\text { gat } \\
\text { Baik }\end{array}$ \\
\hline $\begin{array}{l}\text { Pikiran } \\
\text { Terbuka }\end{array}$ & $\begin{array}{c}70 . \\
6\end{array}$ & Baik & $\begin{array}{c}75 . \\
6\end{array}$ & Baik \\
\hline $\begin{array}{l}\text { Keengganan } \\
\text { Terhadap } \\
\text { Takhayul }\end{array}$ & $\begin{array}{c}82 . \\
6\end{array}$ & $\begin{array}{l}\text { San } \\
\text { gat } \\
\text { Baik }\end{array}$ & 86 & $\begin{array}{c}\text { San } \\
\text { gat } \\
\text { Baik }\end{array}$ \\
\hline $\begin{array}{l}\text { Objektif- } \\
\text { Jujur }\end{array}$ & $\begin{array}{c}63 . \\
7\end{array}$ & $\begin{array}{l}\text { Cuk } \\
\text { up }\end{array}$ & $\begin{array}{c}67 . \\
9\end{array}$ & $\begin{array}{l}\text { Cuk } \\
\text { up }\end{array}$ \\
\hline $\begin{array}{l}\text { Mempertimb } \\
\text { angkan } \\
\text { Keputusan }\end{array}$ & $\begin{array}{c}72 . \\
8\end{array}$ & Baik & $\begin{array}{c}77 . \\
9\end{array}$ & Baik \\
\hline
\end{tabular}

Tabel 3 menunjukkan bahwa aspek setiap sikap ilmiah kelas eksperimen mengalami peningkatan. Sikap ilmiah pada kategori sangat baik terjadi pada aspek ingin tahu dan keengganan 
terhadap takhayul. Hal ini terjadi karena sebagian besar siswa sudah memberi respon positif pada aspek tersebut.

Sikap ilmiah pada kategori baik terjadi pada aspek rasional, pikiran terbuka dan mempertimbangkan keputusan. Hal ini terjadi karena rata-rata siswa sudah memberi respon positif pada aspek tersebut.

Sikap ilmiah pada kategori cukup terjadi pada aspek objektif dan jujur. Hal ini terjadi kemungkinan karena siswa belum dapat menyerap materi pelajaran dengan benar dan belum dapat memahami dengan benar konsep-konsep tertentu. Oleh karena itu, siswa belum dapat mempersepsikan dengan benar objek sikap yang ditanyakan sehingga memberi respon negatif dalam memberi jawaban.

Data pre-test dan post-test sikap ilmiah kelas kontrol ditunjukkan pada Tabel 4 .

Tabel. 4 Persentase Sikap Ilmiah $\frac{\text { Kelas Kontrol }}{\text { Pre-test Post-Test }}$

\begin{tabular}{|c|c|c|c|c|}
\hline Sikap Ilmiah & $\begin{array}{c}\text { Nil } \\
\text { ai } \\
\text { (\%) }\end{array}$ & $\begin{array}{l}\text { Kate } \\
\text { gori }\end{array}$ & $\begin{array}{c}\text { Nil } \\
\text { ai } \\
\text { (\%) }\end{array}$ & $\begin{array}{l}\text { Kate } \\
\text { gori }\end{array}$ \\
\hline Rasional & $\begin{array}{c}71 . \\
7\end{array}$ & Baik & 75 & Baik \\
\hline
\end{tabular}

$\begin{array}{ccccc}\text { Ingin Tahu } & 80 & \text { San } & 81 . & \text { San } \\ & \text { gat } & 2 & \text { gat } \\ & \text { Baik } & & \text { Baik }\end{array}$

Pikiran 70. Baik 75. Baik Terbuka

$3 \quad 6$

\begin{tabular}{|c|c|c|c|c|}
\hline $\begin{array}{l}\text { Keengganan } \\
\text { Terhadap } \\
\text { Takhayul }\end{array}$ & $\begin{array}{c}78 . \\
7\end{array}$ & Baik & $\begin{array}{c}83 . \\
8\end{array}$ & $\begin{array}{l}\text { San } \\
\text { gat } \\
\text { Baik }\end{array}$ \\
\hline $\begin{array}{l}\text { Objektif- } \\
\text { Jujur }\end{array}$ & 64 & $\begin{array}{l}\text { Cuk } \\
\text { up }\end{array}$ & $\begin{array}{c}68 . \\
2\end{array}$ & $\begin{array}{l}\text { Cuk } \\
\text { up }\end{array}$ \\
\hline $\begin{array}{l}\text { Mempertimb } \\
\text { angkan } \\
\text { Keputusan }\end{array}$ & 73 & Baik & $\begin{array}{c}73 . \\
3\end{array}$ & Baik \\
\hline
\end{tabular}

Tabel 4 menunjukkan bahwa bahwa aspek setiap sikap ilmiah kelas kontrol mengalami peningkatan. Sikap ilmiah pada kategori sangat baik terjadi pada aspek ingin tahu dan keengganan terhadap takhayul. Hal ini terjadi karena sebagian besar siswa sudah memberi respon positif pada aspek tersebut. Sikap ilmiah pada kategori baik terjadi pada aspek rasional, pikiran terbuka dan mempertimbangkan keputusan. Hal ini terjadi karena rata-rata siswa sudah memberi respon positif pada aspek tersebut.

Sikap ilmiah pada kategori cukup terjadi pada aspek objektif dan jujur. Hal ini terjadi kemungkinan karena siswa belum dapat menyerap materi pelajaran dengan benar dan belum dapat memahami dengan benar konsep-konsep tertentu. Oleh karena itu, siswa belum dapat mempersepsikan dengan benar objek sikap yang ditanyakan sehingga memberi respon negatif dalam memberi jawaban.

Sikap ilmiah siswa kedua kelas mengalami peningkatan. Namun, sikap ilmiah pada kelas eksperimen lebih tinggi 
dibandingkan dengan kelas kontrol. Hal ini terjadi karena model pembelajaran inquiry training dapat menumbuhkan dan mengembangkan sikap ilmiah siswa pada setiap fase inquiry training.

Proses pembelajaran model inquiry training dalam penelitian ini juga melakukan observasi. Observasi dimaksudkan untuk mengamati keterampilan proses sains siswa selama pembelajaran. Observasi dilakukan oleh dua observer yaitu Nurhayati Saragih, S.Pd.I mahasiswa IAIN SU jurusan Pendidikan Matematika dan guru bidang studi fisika bapak Drs. Armin Suriadi. Pada pelaksanaan observasi, observer diberi lembar deskriptor untuk memudahkan penilaian. Ringkasan hasil observasi keterampilan proses sains siswa pada kelima pertemuan ditunjukkan pada Gambar 1.

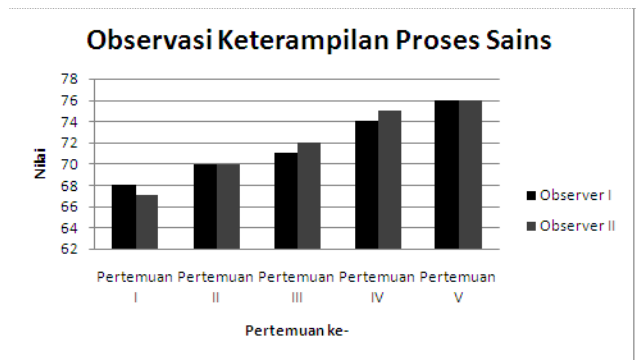

Gambar 1. Observasi

keterampilan proses sains

Gambar 1 menunjukkan bahwa terdapat peningkatan aktivitas keterampilan proses sains dari pertemuan pertama sampai pertemuan kelima dan rata-rata nilai seluruhnya adalah 72 (kategori baik).
Hasil penelitian ini sejalan dengan penelitian terdahulu yang diteliti oleh Sakdiah dan Sahyar (2014) menyatakan bahwa terdapat interaksi antara model pembelajaran inquiry training berbantukan media handout dan direct instruction dengan sikap ilmiah siswa dalam meningkatkan pengetahuan siswa berbasis KPS dan interaksi pada kelas direct instructional lebih baik.

$$
\text { Vaishnav }
$$

menyatakan bahwa the student of the experimental group achieved more score at post test than control group hence it proves the effectiveness of inquiry training model in terms of achievement. It also contribute in increasing the learners aptitude for learning the subject than traditional approach. Hasil belajar siswa pada kelas eksperimen lebih besar dibandingkan dengan kelas kontrol sehingga membuktikan model pembelajaran inquiry training efektif meningkatkan hasil belajar. Model pembelajaran inquiry training juga mampu meningkatkan keterampilan siswa dalam mempelajari sesuatu dibandingkan dengan pembelajaran konvensional.

Damanik dan Bukit (2012) menyatakan bahwa kemampuan berpikir kritis fisika siswa yang menggunakan model pembelajaran inquiry training lebih baik dibandingkan dengan kemampuan berpikir kritis siswa yang menggunakan model pembelajaran direct instruction, namun tidak terdapat interaksi 
antara model pembelajaran inquiry training dan direct instruction pada kemampuan berpikir kritis untuk meningkatkan sikap ilmiah siswa.

Peneliti menemukan kendala menerapkan model pembelajaran inquiry training yaitu adanya siswa yang tidak berperan dalam kegiatan praktikum sehingga mengakibatkan adanya keributan disetiap kelompok. Hal ini disebabkan karena satu kelompok terdiri atas 7 orang sehingga ada beberapa anggota kelompok yang tidak bekerja di dalam kelompoknya. Untuk mengatasi hal ini upaya yang dilakukan adalah sebaiknya jumlah siswa dalam setiap kelompok cukup 3-4 orang saja agar semua siswa bekerja dalam setiap kelompok. Dengan jumlah ini, maka akan memungkinkan setiap siswa dalam setiap kelompok dapat bekerja sama dan semuanya dapat berfungsi untuk melakukan kegiatan praktikum.

Kendala kedua adalah kurangnya alat praktikum berupa multimeter dan bahan berupa bola lampu dan baterai yang tersedia sehingga ketika salah satu alat atau bahan tidak bekerja dengan baik, maka mengganggu aktivitas eksperimen siswa dan hal ini memakan waktu yang cukup banyak untuk memakai alat atau bahan secara bergilir. Untuk mengatasi hal ini, sebelum pembelajaran dimulai sebaiknya peneliti selanjutnya menambah jumlah alat praktikum berupa multimeter dan bahan praktikum berupa bola lampu dan baterai yang diperlukan sehingga tidak terlalu mengganggu aktivitas eksperimen ketika terdapat alat atau bahan yang rusak.

Kendala ketiga, peneliti hanya meneliti aspek keterampilan proses sains dan sikap ilmiah sehingga tidak diketahui bagaimana pengaruh inquiry training terhadap aspek yang lainnya. Untuk mengatasi hal ini, sebaiknya peneliti selanjutnya mencari variabelvariabel yang diamati selain keterampilan proses sains dan sikap ilmiah.

\section{KESIMPULAN DAN SARAN}

Terdapat perbedaan keterampilan proses sains dan sikap ilmiah siswa yang diajarkan menggunakan model pembelajaran inquiry training dengan model pembelajaran langsung pada materi pokok listrik dinamis di kelas $\mathrm{X}$ semester II MAN Kabanjahe sehingga dapat disimpulkan terdapat pengaruh model pembelajaran inquiry training terhadap keterampilan proses sains dan sikap ilmiah siswa pada materi pokok listrik dinamis di kelas X semester II MAN Kabanjahe T.P. 2014/2015.

Kepada peneliti selanjutnya hendaknya membuat perencanaan yang lebih baik pada pengorganisasian kelompok, sebaiknya jumlah siswa dalam setiap kelompok cukup 3-4 orang saja agar semua aktif dalam melakukan praktikum, sebelum pembelajaran dimulai sebaiknya 
menambah jumlah alat
praktikum berupa multimeter
dan bahan praktikum berupa
bola lampu dan baterai yang
diperlukan sehingga tidak terlalu
mengganggu aktivitas
eksperimen ketika terdapat alat
atau bahan yang rusak. Kepada
peneliti selanjutnya juga
sebaiknya mencari variabel-
variabel yang diamati selain
keterampilan proses sains dan
sikap ilmiah.

\section{DAFTAR PUSTAKA}

Damanik, D.P., dan Bukit, N., (2012), Analisis Kemampuan Berpikir Kritis dan Sikap Ilmiah pada Pembelajaran Fisika Menggunakan Model Pembelajaran Inquiry Training (IT) dan Direct Instruction (DI), Jurnal Online Pendidikan Fisika 2(1): 16-24.

Joyce, B., Weil, M., dan Calhoum, M., (2011), Model-Model Pembelajaran Sains, Edisi Delapan, Pustaka Pelajar, Yogyakarta.

Rao, D.B., (2007), Reflections on Scientific Attitude, Discovery Publishing House, India.

Sakdiah, H., dan Sahyar, (2014), Efek Model Pembelajaran Inquiry Training Berbantukan Handout dan Sikap Ilmiah Terhadap Kemampuan Siswa Berbasis Keterampilan Proses Sains (KPS), Jurnal Online Pendidikan Fisika 3(2): 33-39.

$\begin{array}{cc}\text { Sudjana, (2005), } & \text { Metode } \\ \text { Statistika, } & \text { Tarsito, } \\ \text { Bandung. } & \\ \text { Trianto, (2013), } & \text { Model } \\ \text { Pembelajaran } & \text { Terpadu, } \\ \text { Bumi Aksara, Jakarta. } \\ \text { Vaishnav, S.R., (2013), } \\ \text { Effectiveness of Inquiry } \\ \text { Training Model For } \\ \text { Teaching Science, Scholarly } \\ \text { Research Journal for } \\ \text { Interdisciplinary Studies } \\ \text { 1:1216- }\end{array}$
Bandung. Pembelajaran Terpadu, nav, S.R., (2013), Effectiveness of Inquiry Training Model For Teaching Science, Scholarly Interdisciplinary Studies $1 \cdot 1216$ 